\title{
Parasitoids (Hymenoptera: Encyrtidae) of an invasive mealybug Phenacoccus solenopsis Tinsley (Hemiptera: Pseudococcidae) in Turkey
}

İstilacı bir unlubit türü Phenacoccus solenopsis Tinsley (Hemiptera: Pseudococcidae)'in Türkiye'deki parazitoitleri

\author{
A. Filiz ÇALIŞKAN ${ }^{1} \quad$ Mohammad HAYAT $^{2 *}$ \\ M. Rifat ULUSOY' \\ M. Bora KAYDAN ${ }^{3}$

\section{Summary}

Three parasitoids, a hyperparasitoid and an associate parasitoid were recorded on the invasive mealybug, Phenacoccus solenopsis Tinsley (Hemiptera: Pseudococcidae) in Turkey: Anagyrus aligarhensis Agarwal \& Alam, Anagyrus sp. near dactylopii (Howard), Leptomastix epona (Walker), Prochiloneurus uyguni Hayat, sp. n. and Homalotylus hemipterinus (De Stefani). L. epona and $H$. hemipterinus are new records for the fauna of Encyrtidae of Turkey.

Keywords: Associate hyperparasitoid, invasive mealybug parasitoids, Turkey

\section{Özet}

Türkiye'de istilacı unlubit türü Phenacoccus solenopsis Tinsley (Hemiptera: Pseudococcidae) üzerinde üç parazitoit, bir hiperparazitoit ve bir bağlantılı parazitoit türü tespit edilmiştir: Anagyrus aligarhensis Agarwal \& Alam, Anagyrus sp. near dactylopii (Howard), Leptomastix epona (Walker), Prochiloneurus uyguni Hayat, sp. n. ve Homalotylus hemipterinus (De Stefani). L. epona and H. hemipterinus Türkiye Encyrtidae faunası için yeni kayıt türlerdir.

Anahtar sözcükler: Bağlantılı hipeparazitoit, istilacı unlubit parazitoitleri, Türkiye

\footnotetext{
${ }^{1}$ Çukurova University, Agriculture Faculty, Plant Protection Department, Adana, Turkey

2 Department of Zoology, Aligarh Muslim University, Aligarh 202 002, India

${ }^{3}$ Çukurova University, Imamağlu Vocational School, Adana, Turkey

* Corresponding author. e-mail: hayat.mohd44@gmail.com

Received (Alınış): 21.01.2016 Accepted (Kabul ediliş): 19.04.2016 


\section{Introduction}

An invasive mealybug, Phenacoccus solenopsis Tinsley (Hemiptera: Pseudococcidae), cotton or solenopsis mealybug, has a new world origin (Abbas et al., 2010). This mealybug is reported in the Australasian, Afrotropical, Nearctic, Oriental and Neotropical Regions on 202 host plants from 55 families (Garcia et al., 2015; Fand \& Suroshe, 2015; McKenzie, 1967). In the Palaearctic Region it has been recorded in Cyprus, Egypt, France, Iran, Israel, Japan, and recently in Turkey (Garcia et al., 2015; Kaydan et al., 2013). This polyphagous species is regarded as an important pest of cotton (Gossypium hirsutum L., Malvaceae) (Fand \& Suroshe, 2015) and it has caused 30-60\% yield losses in cotton in India and Pakistan in 2005 and 2009 (Fand \& Suroshe, 2015). In addition, P. solenopsis is also an important pest of ornamental plants, such as Hibiscus rosa-sinensis L., H. syriacus L. (Malvaceae) and Lantana camara L. (Verbenaceae), and some vegetable crops, such as Solanum esculentum Lam., S. melongena L. and Capsicum annuum L. (Solanaceae) (Fand \& Suroshe, 2015). This mealybug feeds and develops in the canopy of its host plants and reproduces sexually and through ovoviviparity (Abbas et al. 2010).

Phenacoccus solenopsis is parasitized by 21 species of chalcidoids, 19 of these belong to the hymenopteran family Encyrtidae, one each to the Eulophidae and Signiphoridae (Noyes, 2015).

In this study, we recorded three primary parasitoids, one hyperparasitoid, and one primary parasitoid of the larvae of the Coccinellidae (Coleoptera) feeding on P. solenopsis in Turkey and one new species is described, namely Prochiloneurus uyguni Hayat, sp. $\mathrm{n}$.

\section{Material and Methods}

Mealybug samples including parasitized and unparasitized samples were collected from ornamental plants from Adana, Turkey. Each sample was placed in a plastic bag and taken to the laboratory for examination. Mealybug specimens were prepared for light microscopy using the slidemounted method of Kosztarab \& Kozár (1988) and identified according to key of Williams (2004). Identification of mealybug was made by one of us (Mehmet Bora KAYDAN).

The specimens were reared from the mealybug, and initially preserved in $80 \%$ alcohol. These were card-mounted, and at least one specimen of each species (or parts of one specimen) were mounted on slides.

The terminology of Hayat (2006) is followed, except for the use of the terms mesosoma for the thorax plus propodeum, and metasoma for the petiole plus gaster. Only body lengths are given in millimeters; all other measurements are relative, taken with the help of an ocular micrometer with a linear scale of 100 divisions, placed in the eye piece of a stereo zoom binocular microscope (one micrometer division $=0.01234 \mathrm{~mm}$ ) for card-mounted specimens, and placed in the eye piece of a compound microscope at 100X magnification (one micrometer division $=0.00987 \mathrm{~mm}$ ) for slide-mounted parts.

The following abbreviations are used in the text:

$\mathrm{AOL}=$ minimum distance between a posterior ocellus and the anterior ocellus.

F1, F2, onwards = Funicle segments 1, 2, onwards.

$\mathrm{OCL}=$ minimum distance between a posterior ocellus and the occipital margin .

$\mathrm{OOL}=$ minimum distance between a posterior ocellus and the corresponding eye margin .

$\mathrm{POL}=$ minimum distance between the posterior ocelli.

TI, TII, onwards $=$ Tergites 1,2 onwards of the gaster.

The following acronym is used for the depository:

ZDAMU = Insect Collections, Department of Zoology, Aligarh Muslim University, Aligarh, India. 


\section{Result and Discussion}

\section{Primary parasitoids}

\section{Anagyrus aligarhensis Agarwal \& Alam (Figures 1-11)}

Anagyrus diversicornis Mercet, 1921: 134-135, female. Spain. Preoccupied in Anagyrus by $A$. diversicornis (Howard, 1894).

Anagyrus aligarhensis (Man Mohan) Agarwal \& Alam, 1959: 392, female, male. India, Aligarh. Next available name for diversicornis Mercet.

Anagyrus aligarhensis Agarwal, 1965: 52-53, female, male. Redescription of aligarhensis Agarwal \& Alam, 1959, as new species.

Anagyrus micans Noyes, 2000: 2, 36. Unnecessary replacement name for diversicornis Mercet, not Howard. Synonymy by Hayat, 2003: 189.

For further synonyms and misidentifications, see Noyes \& Hayat (1994).

This species is widely distributed in the old world, and introduced into the USA. A redescription of the species and some relevant figures are given here based on the Turkish specimens.

\section{Redescription}

Female. Length, $1.15-1.30 \mathrm{~mm}(\mathrm{n}=4)$. Body dark brown, except as follows: occiput behind eyes, and frontovertex along eye margins orange yellow (Fig. 1); malar space with a yellow streak from below eye margin; collar of pronotum white, interrupted by a dark brown band in lateral fourth and sides anteriorly brownish yellow; tegula white, apically dark brown (Fig. 2); prepectus white; mesopleuron brown, but anteriorly, dorsally and posteriorly yellow. Antenna (Fig. 5) with radicle, scape except a small basal spot and a subapical curved band, pedicel in about distal third, F2 and F3, white; F1 dark brown; F4-6 pale brown; clava pale brownish yellow. Mandible in about apical half reddish brown. Wings hyaline; fore wing with discal setae pale brown; hind wing with discal setae translucent. Legs, including coxae, largely white, except brown to dark brown as follows: fore leg with coxa in one specimen with a brown streak in basal half on outer margin; femur with brownish streaks on both margins; tibia brownish yellow; tarsus brownish yellow, fifth segment brown; mid leg with coxa in about basal half on ventral surface brown; femur with a brownish streak on outer surface; tibia with a subbasal brownish infuscation; tarsal segments 1-4 yellowish white, fifth segment dark brown; hind leg with coxa largely brown to dark brown; femur largely brownish, becoming yellowish apically; tibia whitish yellow with pale brown infuscation; tarsal segments 1-4 brownish yellow, fifth segment dark brown.

Head. Frontovertex width 0.45X head width; head, in frontal view (Fig. 3), 1.18X as broad as high; antennal torulus with upper margin at most in line with lower margin of eye; eye height 2.63X malar space; frontovertex and face with raised, rugose-reticulate sculpture (Figs 3 and 4); head densely setose, setae silvery white; eye setose, setae hyaline, each seta shorter than a facet diameter. Antenna (Fig. 5) with scape $2.3 \mathrm{X}$ as long as broad; pedicel subequal in length to F1; F2-6 each distinctly longer than broad, and each shorter than F1; clava shorter than F4-6 combined.

Mesosoma (Fig. 2). Mesoscutum and scutellum with rugose-reticulate sculpture, that on scutellum not deeper than on mesoscutum; mesothorax densely setose, setae silvery white; propodeum with silvery white setae, a few mesal to spiracle and several setae distal to spiracle. Fore wing 2.6X as long as broad; setae and venation as in Figs 6 and $6 \mathrm{a}$. Hind wing $5 \mathrm{X}$ as long as broad. Mid tibia $3.2 \mathrm{X}$ as long as mid basitarsus; mid tibial spur shorter $(0.8 \mathrm{X})$ than mid basitarsus. Relative measurements (from slide): fore wing length (width), 115 (44); hind wing length (width), 85 (17); mid tibia length, 48; mid basitarsus length, 15; mid tibial spur length, 12. 

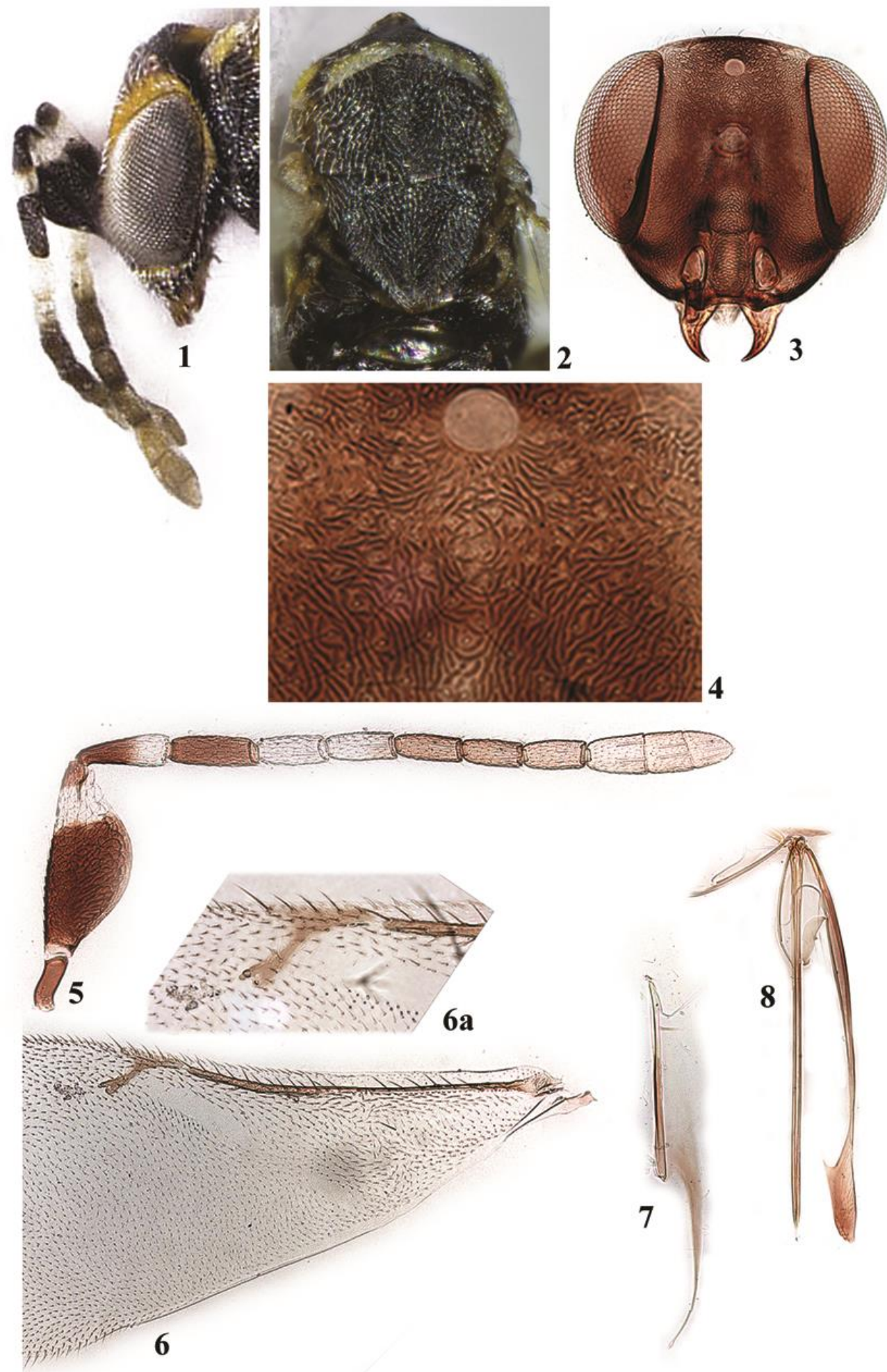

Figures 1-8. Anagyrus aligarhensis Agarwal \& Alam, female: 1. head, in profile, with antennae; 2. mesosoma dorsal; 3. head, frontal view; 4 . sculpture on frons; 5 . antenna; 6 . fore wing; $6 \mathrm{a}$, distal veins of fore wing; 7 . outer plate of ovipositor; 8 . ovipositor. 


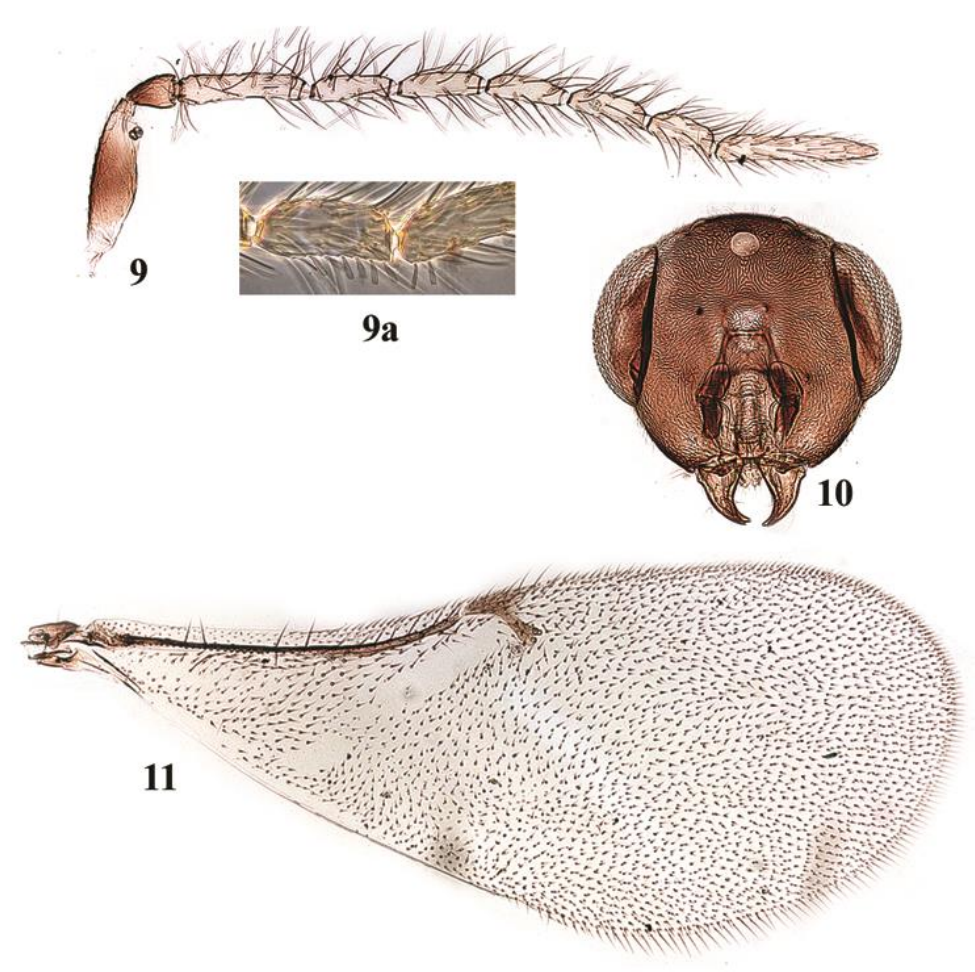

Figures 9-11. Anagyrus aligarhensis Agarwal \& Alam, male: 9. antenna; 9a. F6 and basal part of clava enlarged showing scale-like sensilla; 10. head, frontal view; 11. fore wing.

Metasoma elongate, longer than head and mesosoma combined, and 1.53X as long as mesosoma; ovipositor as in Fig. 8; outer plate of ovipositor as in Fig. 7; ovipositor with second valvifer $3.55 \mathrm{X}$ as long as third valvula. Relative measurements (from slide): TVII length, 66; ovipositor length, 82; third valvula length, 18. [Ovipositor 1.7X as long as mid tibia; third valvula longer than both mid basitarsus and mid tibial spur.]

Male. Length, $0.74-0.92 \mathrm{~mm}(\mathrm{n}=3)$. Similar to female in color and sculpture, but differs in antennal structure, genitalia, and head dimensions.

Head, in frontal view (Fig. 10), 1.3X as broad as high; frontovertex width 0.56X head width; antennal torulus with lower margin in line with lower margin of eye; eye height 1.82X malar space. Antenna as in Fig. 9; F6 and clava basally with scale-like sensilla (Fig. 9a). Fore wing 2.35X as long as broad, venation and discal setation as in Fig. 11. Hind wing 5.95X as long as broad, and 0.73X fore wing length. Gaster as long as mesosoma; phallobase without digiti, and 0.88X mid tibia length.

Material examined. 5 females, 4 males. TURKEY: Adana, 5 females (one on slide, No. EH.1792), 12.ix.2014, Coll. A.F. Çalışkan (No. 31-d); Adana, 2 males (one on slide, No. EH.1798), 4.ix.2014, Coll. A.F. Çalışkan (No. 7-b); 1 male, 12.ix.2014, Coll. A.F. Çalışkan (No. 31-b); 1 male, 12.ix.2014, Coll. A.F. Çalışkan (No. 37). All specimens ex Phenacoccus solenopsis on Hibiscus rosa-sinensis L. (Malvaceae). (ZDAMU)

Hosts. Phenacoccus solenopsis Tinsley, in Turkey (new host record). See Noyes \& Hayat (1994) for other host records. 
Distribution. England, Spain, western and southern former USSR, Hungary, Portugal, Italy, Bulgaria, former Yugoslavia, Romania, France, Turkey, Iran, India, Nepal, China, Indonesia; USA (Texas, introduced) (Noyes \& Hayat, 1994).

\section{Anagyrus sp. near dactylopii (Howard) (Figures 12-19)}

Female. Length, $1.7 \mathrm{~mm}$. Habitus, Fig. 12. Head yellow; occiput and intertorular area brown; mouth margin and malar space dark brown. Antenna with radicle, scape except a small basal spot and a subapical curved white band, dark brown; pedicel in about basal third dark brown, distal two-thirds white; F1 dark brown; F2-6 and clava, white. Mesosoma yellow except as follows: pronotum in about middle half and anterior fourth of mesoscutum, dark brown; sutures dark brown; axilla and scutellum washed with pale brownish yellow; scutellum with a mid-longitudinal brown streak; metanotum laterally brown; propodeum mesal to spiracles and along lateral margins brown. Fore wing hyaline, with discal setae especially distal to linea calva minute, and translucent. Hind wing hyaline. Legs, including fore and mid coxae, white; both margins of fore femur and fore tibia pale brown; upper (= outer) margin of mid femur pale brown; extreme base of mid tibia dark brown, and with a diffuse pale brown infuscation in about basal third; hind femur washed with very pale brown; extreme base of hind tibia with a small dark brown spot, and its outer margin pale brown. Gaster dark brown; ovipositor sheaths (= third valvulae) dark brown.

Head. Frontovertex width 0.32X head width; head, in frontal view (Fig. 14), 1.14X as broad as high; antennal torulus close to mouth margin and with upper margin below lower margin of eye; eye height 2.53X malar space; frontovertex with raised rugose-reticulate sculpture (Fig. 14a); setae on head silvery white; eye setose, setae brown, and each seta at least about as long as a facet diameter. Antenna with scape $2 \mathrm{X}$ as long as broad, otherwise as in Fig. 13. Relative measurements (from slide): head frontal width, 58; head frontal height, 51; frontovertex width, 18.5; eye height, 38; malar space, 15; antennal scape length (width), 32 (16).

Mesosoma. Sculpture on mesoscutum and scutellum as in Figs 15 and 16; setae silvery white, except two pairs of brown setae subapically on scutellum; propodeum with silvery white setae, 5-6 proximal to each spiracle, and several setae distal to each spiracle. Fore wing $2.28 \mathrm{X}$ as long as broad; venation reaching to $0.52 \mathrm{X}$ wing length; costal cell with a single line of setae on ventral surface in distal two-thirds, and 3-4 lines in basal third; postmarginal vein virtually absent or very short, both combined $0.56 \mathrm{X}$ stigmal vein; linea calva interrupted posteriorly by 6-7 lines of setae, and the basal cutoff portion nearly rounded (Figs 19 and 19a). Hind wing 3.65X as long as broad. Mid tibia 2.94X as long as mid basitarsus; mid tibial spur $0.84 \mathrm{X}$ mid basitarsus length. Relative measurements (from slide): mesosoma length, 70; mesoscutum length (width), 30 (50); scutellum length (width), 31 (34); fore wing length (width), 132.5 (58); hind wing length (width), 95 (26); mid tibia length, 56; mid basitarsus length, 19; mid tibial spur length, 16.

Metasoma. Ovipositor as in Fig. 17; outer plate of ovipositor as in Fig. 18. Relative measurements (from slide): TVII length, 65; ovipositor length, 60; third valvula length, 12.5. [Ovipositor slightly longer than mid tibia, 60:56; third valvula distinctly shorter than both mid basitarsus and mid tibial spur, 12.5:19:16.]

\section{Male. Unknown.}

Material examined. 1, female (on slide under 5 coverslips, slide No. EH.1794). TURKEY: Adana, 12.ix.2014 Coll. A.F. Çalışkan (31-c) and ex Phenacoccus solenopsis on Hibiscus rosa-sinensis L. (ZDAMU)

Host. Phenacoccus solenopsis on Hibiscus rosa-sinensis L. (Malvaceae).

Distribution. Turkey (Adana). 

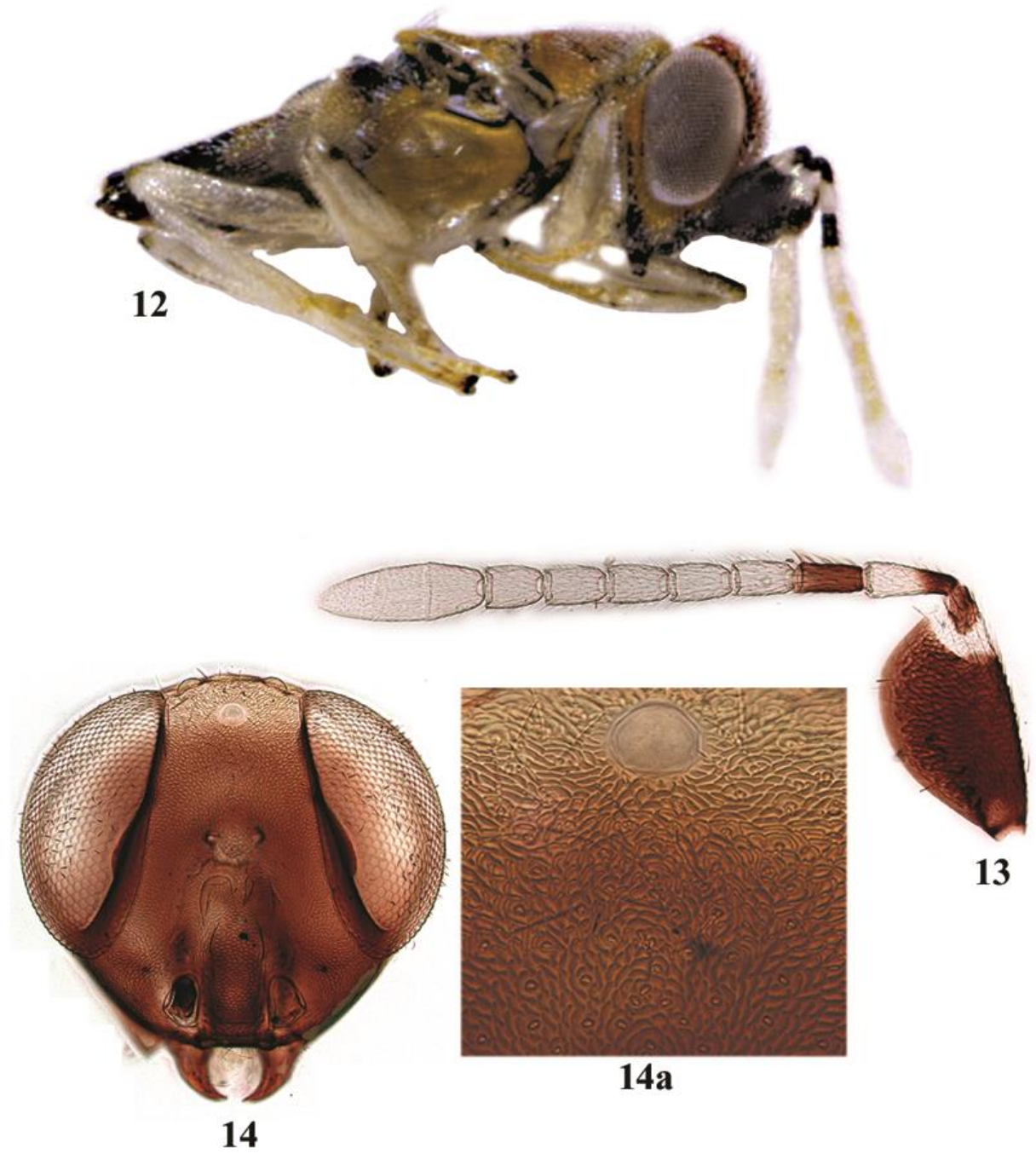

Figures 12-14. Anagyrus sp. near dactylopii (Howard), female: 12. body, lateral view; 13. antenna; 14. head, frontal view; $14 a$. sculpture on frons.

Comments. This Anagyrus sp. is apparently similar to A. dactylopii (Howard) based on the description and key characters given by Noyes \& Hayat (1994) (See also the paper on A. pseudococci (Girault) and related species or forms, by Triapitsyn et al., 2007). However, it differs from $A$. dactylopii, $A$. pseudococci and Anagyrus chrysos Noyes \& Hayat (1994), by the following combination of characters: frontovertex width nearly one-third head width; antennal scape $2 X$ as long as broad; fore wing with postmarginal vein very short or absent; costal cell with a single line of setae on ventral surface in distal two-thirds which become 3-4 lines in proximal third; ovipositor slightly longer than mid tibia; third valvula (fused with second valvifer, a generic character) short, $0.26 \mathrm{X}$ second valvifer length, and distinctly shorter than mid basitarsus or mid tibial spur.

We initially considered this species from Turkey as a new species, but following the opinion of one of the reviewer, eventually decided to regard it as a species near $A$. dactylopii. However, we are describing this form or strain reared from $P$. solenopsis in Turkey because it may eventually prove to be of help to those dealing with the identities of the pseudococci-complex based on the morphological characters. 


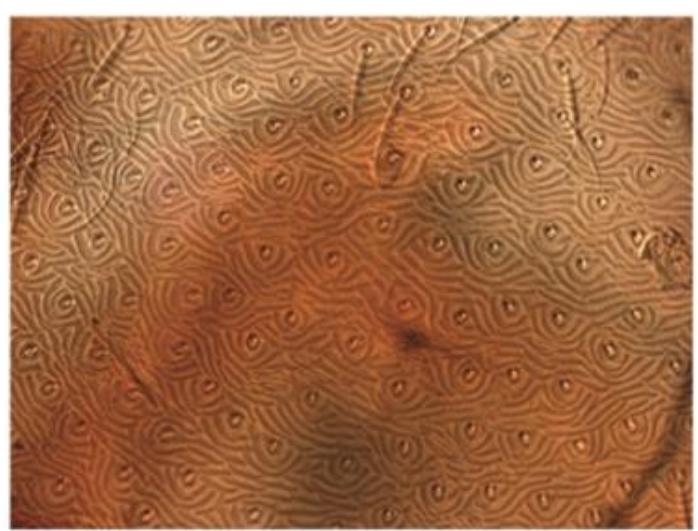

15

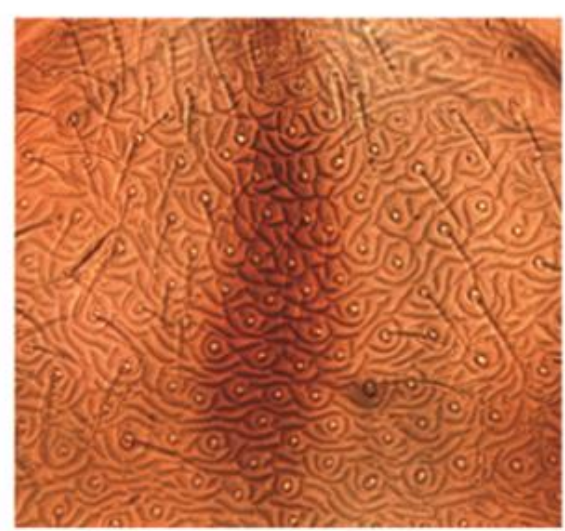

16
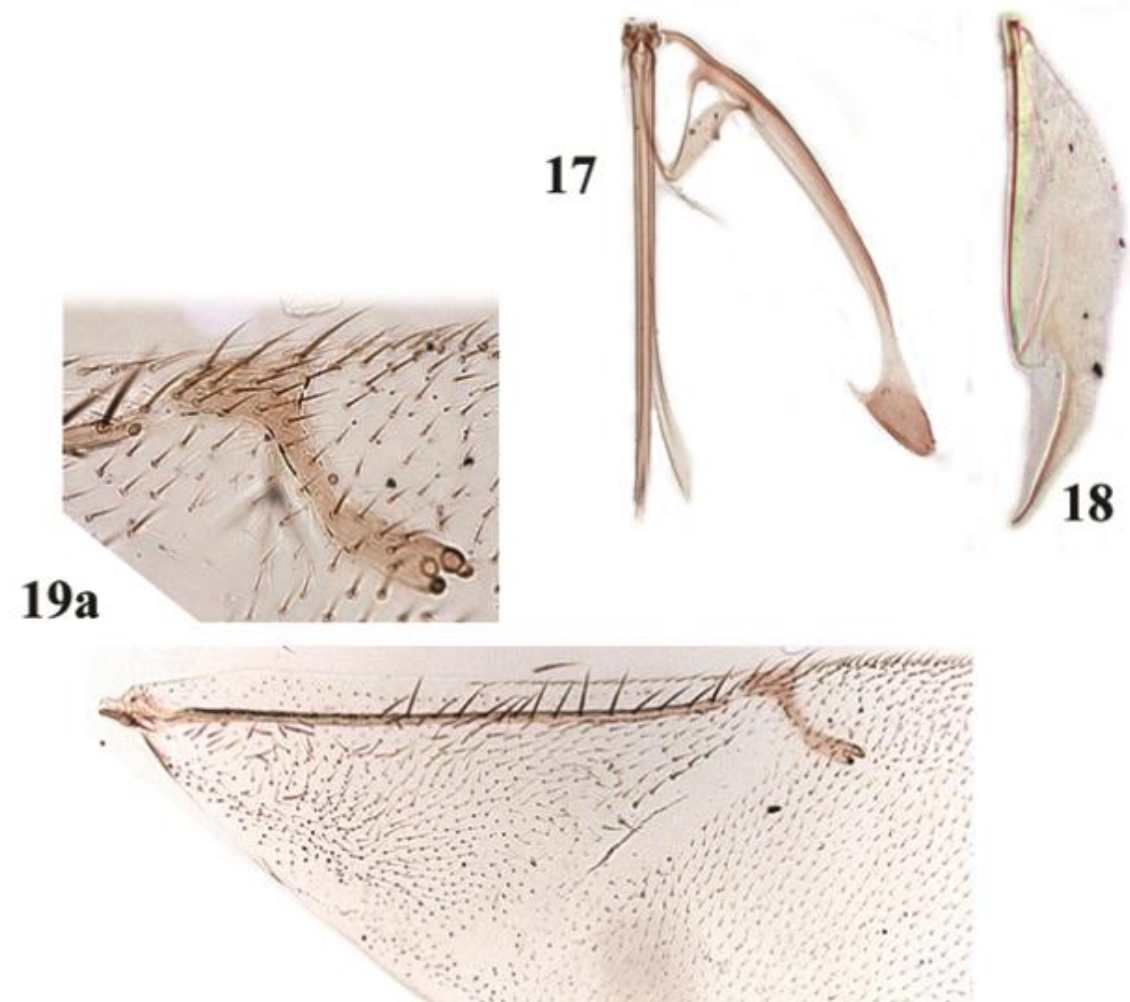

19

Figures 15-19. Anagyrus sp. near dactylopii (Howard), female: 15. sculpture on mesoscutum; 16. sculpture on scutellum; 17. ovipositor; 18. outer plate of ovipositor; 19. fore wing, basal part; 19a. distal veins of fore wing. 


\section{Leptomastix epona (Walker) (Figures 20-31)}

Encyrtus epona Walker, 1844: 184, male.

Leptomastix epona (Walker): Graham, 1969: 217.

Leptomastix histrio Mayr: Mercet, 1921: 123, female, male. Misidentification of L. epona according to Graham, 1969: 217.

\section{Redescription}

Female. Length, $1.49 \mathrm{~mm}, 1.75 \mathrm{~mm}$. Body completely dark brown to nearly black (Fig. 20). Head in one specimen with a fine yellow line along each eye margin (Fig. 22). Antenna dark brown; scape ventrally yellow. Scutellum dark brown to yellowish brown, but in one specimen nearly black. Wings hyaline. Legs, including fore coxa, yellow to brownish yellow, except as follows: mid and hind coxae dark brown; mid femur in about basal two-thirds, hind femur except apex, dark brown; fore tarsus brown; mid tarsus with segments 1-4 each apically brown, fifth segment dark brown; hind tarsus with basitarsus brownish yellow, second segment onwards gradually becoming brown to dark brown. In one specimen, fore coxa dark brown; fore femur brown in about basal half; mid femur except apex, dark brown. Gaster with $\mathrm{TI}$ across base and postero laterally yellow, with a black spot on each side; in one specimen $\mathrm{TI}$ completely dark brown; ovipositor sheaths dark brown.

Head (Fig. 21). Occipital margin sharp; head, in dorsal view, 2.45X as broad as frontovertex or frontovertex width $0.4 \mathrm{X}$ head width; ocellar triangle with apical angle a right angle; POL, OOL, OCL, ratios, 9:3:4; head, in frontal view, 1.08X as broad as high, but on slide 1.18X as broad as high (Fig. 22); scrobes inverted U-shaped, margins rounded; intertorular area convexly elongate with a mid-longitudinal ridge; head, in profile, with eye height 3.27X malar space; frontovertex with slightly raised polygonal reticulate sculpture, the cells small (Fig. 22a), and with sparse, silvery white setae; the sculpture fine on facial region, and elongate reticulate on malar space; eye bare. Antenna (Fig. 23) with scape about $7 \mathrm{X}$ as long as broad; F1 nearly $2 \mathrm{X}$ as long as pedicel; clava slightly shorter than F5 and F6 combined. Relative measurements (from card): head dorsal width, 54; frontovertex width, 22; head frontal height, 50; eye height, 36; malar space, 11.

Mesosoma (Fig. 21). Pronotum with transversely elongate reticulate sculpture; mesoscutum with fine polygonal reticulate sculpture; axilla with slightly raised, reticulate sculpture; scutellum with irregular, polygonal reticulations, only slightly deeper than on mesoscutum; pronotal collar with brown setae; mesoscutum with off-white to pallid setae, except brown setae along posterior margin; scutellum with offwhite to pallid setae, except 4 brown subapical setae; propodeum on both sides of spiracle with white setae. Fore wing $2.77 \mathrm{X}$ as long as broad; marginal vein at least $1.3 \mathrm{X}$ as long as postmarginal vein which is subequal in length to stigmal vein; otherwise, wing venation and discal setation as in Fig. 25 . Mid tibia $3 \mathrm{X}$ as long as mid basitarsus; mid basitarsus slightly longer than mid tibial spur. Relative measurements (from slide): fore wing length (width), 172 (62); mid tibia length, 84; mid basitarsus length, 28; mid tibial spur length, 26.

Metasoma. Ovipositor and outer plate as in Fig. 26. Relative measurements (from slide): TVII length, 80; ovipositor length, 49; third valvula length, 7. [Ovipositor $0.58 \mathrm{X}$ mid tibia length; third valvula $0.25 \mathrm{X}$ mid basitarsus length, and $0.27 \mathrm{X}$ mid tibial spur length.]

Male. Length, $1.05-1.46 \mathrm{~mm}(\mathrm{n}=6)$. Color, especially of the head, and mesoscutum and scutellum variable. Head varies from dark brown with narrowly yellow along eye margins, and brownish yellow between toruli to mouth margin; the bands along eye margins may be broader, and facial region and malar space completely yellow to pale brownish yellow (Fig. 29). Antenna dark brown, with radicle nearly black, and ventral half of scape yellow to brownish yellow. Mesosoma completely dark brown, but mesoscutum on sides from narrowly brownish yellow to one-fourth to one-third of sides yellow to brownish yellow; scutellum dark brown to yellowish brown with brown to completely yellow apically (Fig. 27). Leg color about as in female, but fore femur except apex brown to completely yellow; mid femur brownish yellow, and hind femur dark brown except pale apex to light brown; fore tarsus brown; mid tarsus with segments 1-3 segments apically dark brown, segments fourth and fifth dark brown; hind tarsal segment 1 or segments 1 and 2 yellowish, segments $2-5$ or 3-5 dark brown. 


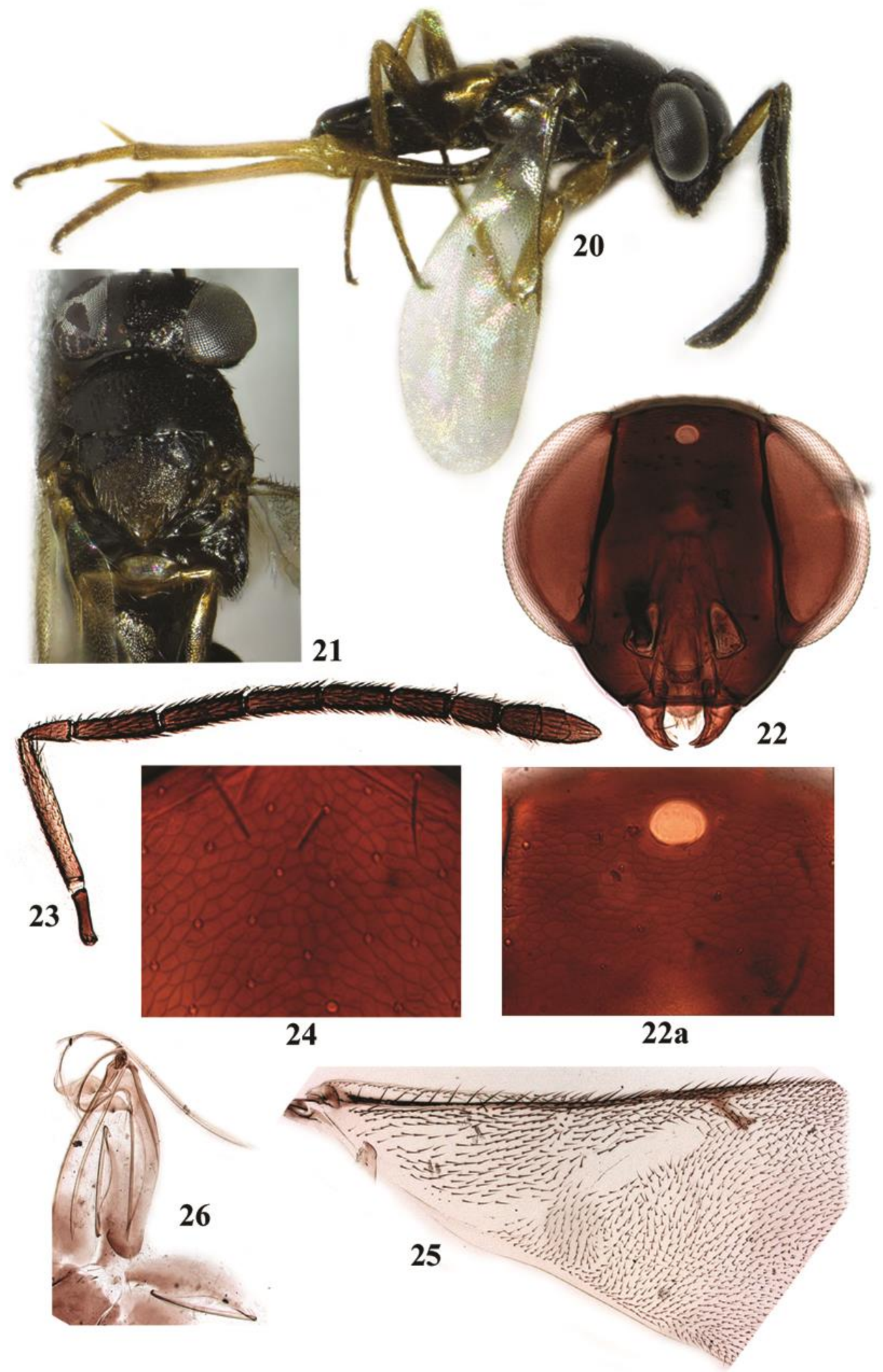

Figures 20-26. Leptomastix epona (Walker), female: 20. body, lateral view; 21. head, mesosoma and TI of gaster, dorsal view; 22. head, frontal view; 22a. sculpture on frons; 23. antenna; 24. sculpture on scutellum; 25. fore wing, basal half; 26. ovipositor and outer plate. 


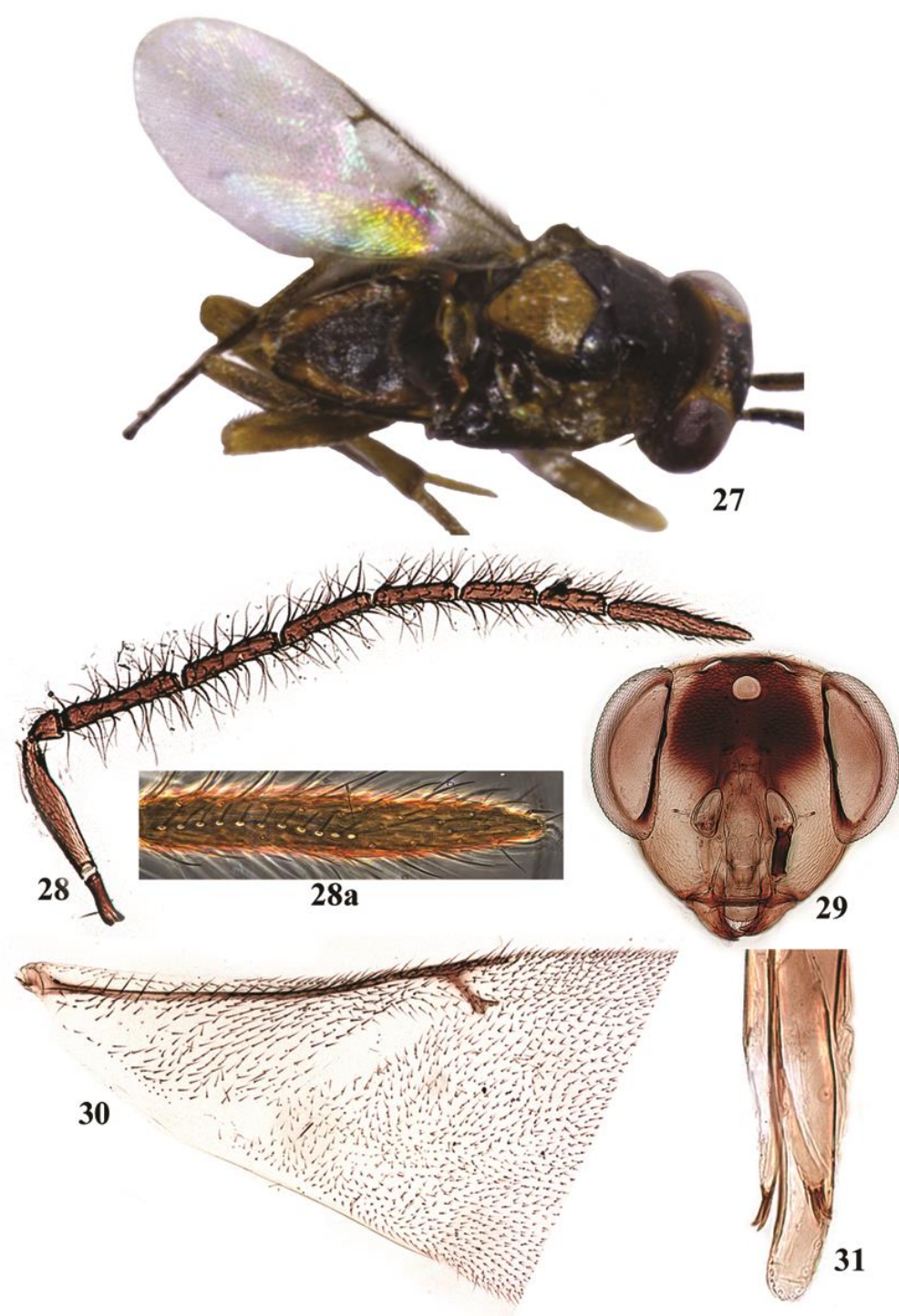

Figures 27-31. Leptomastix epona (Walker), male: 27. body, dorsolateral view; 28. antenna; 28a. clava enlarged showing scale-like sensilla; 29. head, frontal view; 30. fore wing, basal half; 31. genitalia, distal part.

Head (Fig. 29) with frontovertex width about 0.5X head width; torulus with lower margin in line with lower margin of eye. Antenna as in Fig. 28; only clava with a line of scale-like sensilla (Fig. 28a). Fore wing venation and setation as in Fig. 30. Genitalia (Fig. 31) with phallobase (20) slightly shorter than mid tibial spur (22.5).

Material examined. 3 females, 8 males. TURKEY: Adana, 3 females (one on slide, No. EH.1795), 12.ix.2014, Coll. A.F. Çalışkan (No. 31-b); Adana, 6 males (two on slides, Nos. EH.1796 and EH.1876), 12.ix.2014, Coll. A.F. Çalışkan (No. 31-c); Adana, 1 male, 4.ix.2014, Coll. A.F. Çalışkan (No. 12-b); Adana, 1 male, 4.ix.2014, Coll. A.F. Çalışkan (No. 18). All specimens ex Phenacoccus solenopsis on Hibiscus rosa-sinensis L. (Malvaceae). (ZDAMU)

Hosts. Phenacoccus solenopsis Tinsley in Turkey (new host record). For other hosts see Noyes (2015).

Distribution. Turkey (new record). Recorded from several countries in the Palearctic Region, and the USA (California) (See Noyes, 2015). 
Comments. The problem with the identity of Leptomastix epona (Walker, 1844) is a little complicated and dealt with by Graham (1969). In short, it may be stated that the genus Leptomastix Foerster (1856) was erected without any included species, and it was Mayr (1876) who included his (new) species, histrio which thus became the type species by subsequent reference. Foerster in the same paper (1856) described Sterrhocoma and included one species, histrio Foerster. Graham (1969: 216218) synonymized Sterrhocoma with Leptomastix, and has shown that L. histrio Mayr of Mercet (1921: 121-123) is a misidentification for L. epona (Walker). It is, however, not clear how L. histrio (Foerster) differs from L. histrio Mayr or L. epona (Walker). As $L$. histrio (Foerster, 1856) is a senior homonym of $L$. histrio Mayr (1876), Özdikmen (2011: 804) proposed the replacement name L. mayri Özdikmen for the junior homonym.

The specimens identified as $L$. epona may be confused with $L$. algirica Trjapitzin (1989). However, Anga \& Noyes (1999) note that $L$. algirica may be a black form of $L$. epona since they indicated that it was not possible to find any consistent morphological characters to separate the two species.

It is apparent that the problem of identity of $L$. histrio (Foerster) remains unsolved. Our identification of the Turkish Leptomastix as L. epona is largely based on the description of the male by Walker (1844), and of both sexes of epona misidentified by Mercet (1921) as histrio Mayr. This is also supported by the presence of pale setae on the mesoscutum and scutellum of epona as given in the key by Graham (1969: 213). We have, therefore, redescribed $L$. epona based on the Turkish specimens obtained from Phenacoccus solenopsis.

\section{Hyperparasitoid}

\section{Prochiloneurus uyguni Hayat, sp. n. (Figures 32-34)}

Female. Holotype (Fig. 32). Length, $1.2 \mathrm{~mm}$. Head dark brown; face in scrobal impression brownish yellow; occiput brownish yellow with dark brown in upper part; frontovertex with purple shine. Antenna (Figs 32 and 33) with scape pale yellow, with base and both margins dark brown, except apex yellow; pedicel, F1and F2 brown, F3-5 white, and F6 dark brown; clava dark brown to nearly black. Mesosoma with pronotal collar white, otherwise pronotum brownish yellow and medially dark brown; mesoscutum dark brown; axilla yellowish brown; scutellum dark brown; tegula brownish yellow, apically brown; metanotum pale brown; propodeum brown; prepectus yellow; mesopleuron anteriorly yellow, becoming in large part pale brownish yellow. Fore wing (Fig. 34) hyaline in basal two-sevenths and apically, rest infuscate, the infuscation distally convex, with the width of the hyaline apex one-sixth of width of infuscated area. Hind wing hyaline. Legs with all coxae and trochanters white; fore leg with femur white, dark brown in distal fourth or so; tibia yellow with a faint brown streak on outer surface; tarsus yellow to brownish yellow; mid leg with femur white, brownish along outer surface in distal half, except white apex; tibia brownish from base to near apex, the apex nearly white; tarsus and spur white; hind leg with femur yellowish white with a brownish streak on inner surface in about distal half; tibia dark brown with base and a streak at apical fifth on outer surface, white; tarsus with segments 1-4 white, fifth brownish yellow. Gaster dark brown with violet and greenish blue shine; exserted part of ovipositor yellow.

Head. Occipital margin sharp, concave between eyes; frontovertex width one-sixth $(0.16 \mathrm{X})$ head width; eye posteriorly separated from occipital margin by about two facet diameters; ocellar triangle with apical angle acute; posterior ocellus touching eye margin; OOL 2X POL, and 0.5X AOL; head, in frontal view, 1.36X as high as broad; upper margin of facial impression straight, transverse and reaching only to one-fourth head height; head, in profile, with eye height 1.68X malar space; vertex with raised, polygonal reticulate sculpture, the cells very small; frons with hardly raised sculpture; frontovertex with sparse, short, white setae; eye apparently bare. Antenna (Fig. 33) with scape 6X as long as broad; pedicel as long as F1 and F2 combined; F1 slightly longer than broad, F 2-5 quadrate to slightly broader than long; F6 nearly $1.5 \mathrm{X}$ as broad as long; clava large, strongly truncate, and as long as funicle. Relative measurements (from card): head dorsal width, 30; frontovertex width, 5; head frontal height, 41; eye height, 27; malar space, 16; distance from mouth margin to upper margin of facial impression, 10. 


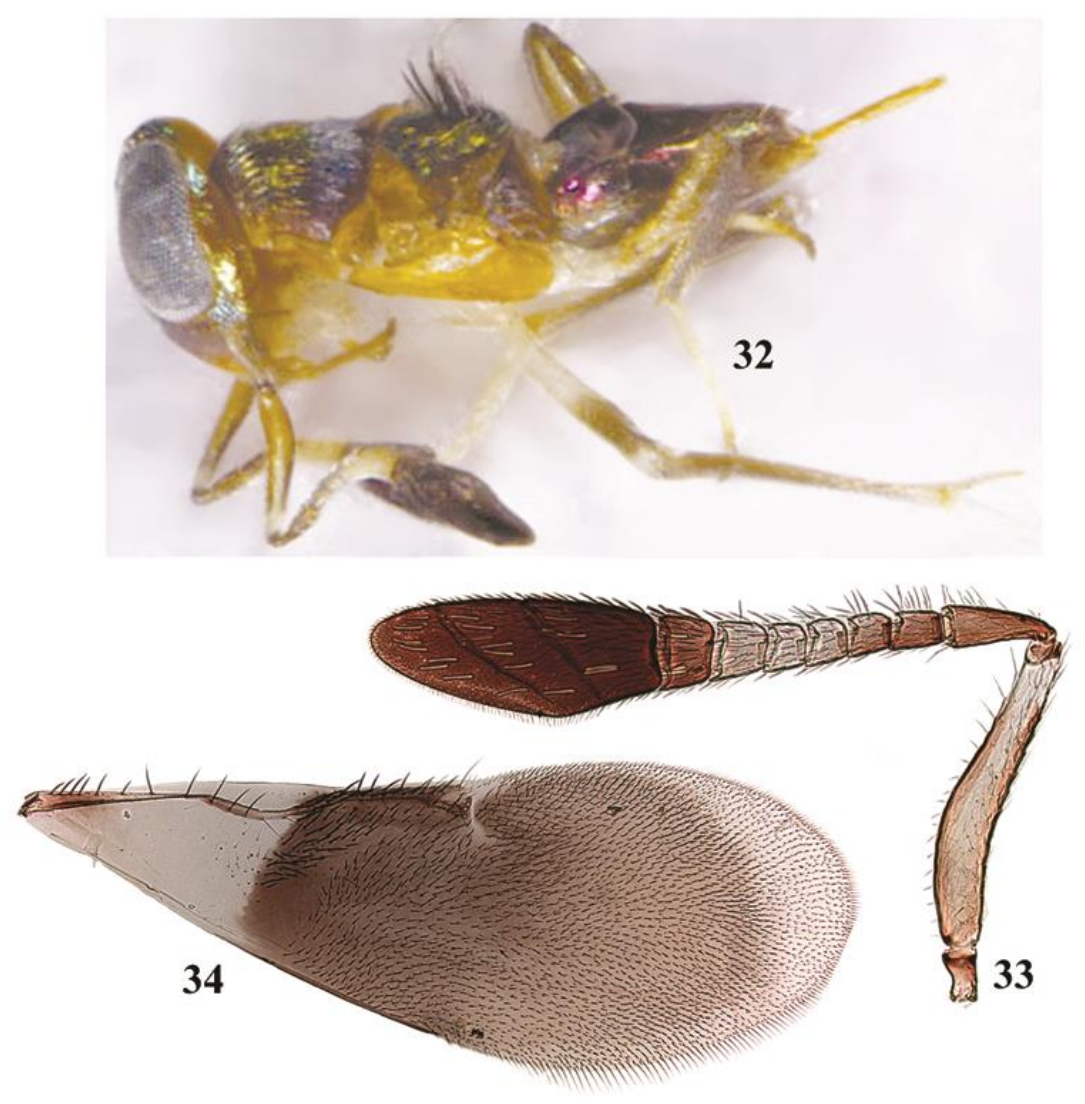

Figures 32-34. Prochiloneurus uyguni Hayat, sp. n., holotype, female: 32. body, lateral view; 33. antenna; 34. fore wing.

Mesosoma (Fig. 32) 1.25X as long as metasoma; mesoscutum in about anterior half with slightly raised polygonal reticulate sculpture and in about posterior half finely reticulate; scutellum with raised, polygonal reticulate sculpture, cells very small; pronotal collar with silvery white setae; mesoscutum in about anterior half with golden brown setae, in about posterior half with silvery white setae; axilla (strongly elevated above surface of scutellum) with largely brown setae; scutellum with golden brown setae; scutellar brush of black setae (14 long setae followed by several shorter setae, about two-thirds the length of the longer setae); with a subapical pair of white, recurved setae; propodeum with sides, proximal as well as distal to spiracles, with silvery white setae. Fore wing (Fig. 34) $2.76 \mathrm{X}$ as long as broad; disc in basal hyaline area with a few translucent setae adjacent to proximal margin of infuscation; apical hyaline area with brown setae. Hind wing $3.56 \mathrm{X}$ as long as broad. Relative measurements (from card): mesosoma length, 44; mesoscutum length (width), 20 (32); scutellum length (width), 19 (21); (from slide, at 100X): fore wing length (width), 108 (39); hind wing length (width), 89 (25).

Metasoma (Fig. 32) with exserted part of ovipositor $0.62 \mathrm{X}$ gaster length.

Male. Unknown.

Material examined. Holotype (ZDAMU; registration No. HYM.CH.735), female (on card, with one antenna and both fore wings and left hind wing, on slide, No. EH.1797), labeled "TURKEY: Adana, 12.ix.2014 Coll. A.F. Çalışkan (41-b)" and "Phenacoccus solenopsis on Lantana camara L."

Host. Hyperparasitoid on encyrtid primary parasitoid of Phenacoccus solenopsis on Lantana camara L. (Verbenaceae).

Distribution. Turkey (Adana). 
Etymology. This species is named after one of the most well-known entomologists who worked on the Coccinellidae (Coleoptera) in Turkey, Prof. Dr. Nedim Uygun (Çukurova University, Agriculture Faculty, Plant Protection Department, Adana, Turkey).

Comments. This new species was initially confused with $P$. dactylopii (Howard) [Synonym: Achrysopophagus argentinensis De Santis, 1964], but differs in several characters: head and mesosoma, except axilla, dark brown; head, in frontal view, 1.36X as high as broad; frontovertex width one-sixth head width; posterior ocellus touching eye margin; eye height 1.68X malar space; antennal scape $6 \mathrm{X}$ as long as broad; and width of hyaline apex of fore wing one-sixth width of infuscate area. In $P$. dactylopii, based on the description given by De Santis (1964): head and mesosoma orange yellow, with posterior third of mesoscutum dark brown; head, in frontal view, as broad as high; frontovertex width one-fourth head width; posterior ocellus separated from eye margin by one ocellus diameter; eye height $1.45 \mathrm{X}$ malar space; antennal scape $4.63 \mathrm{X}$ as long as broad; width of hyaline apex of fore wing $0.4 \mathrm{X}$ width of infuscate area.

\section{Associate parasitoid of predator}

\section{Homalotylus hemipterinus (De Stefani) (Figures 35-38)}

Homalotylus hemipterinus (De Stefani): Noyes, 2010: 146-148, female, male, figures, synonymy, diagnosis, material listed from several countries in the Palaearctic, Oriental, Afrotropical and Neotropical Regions.
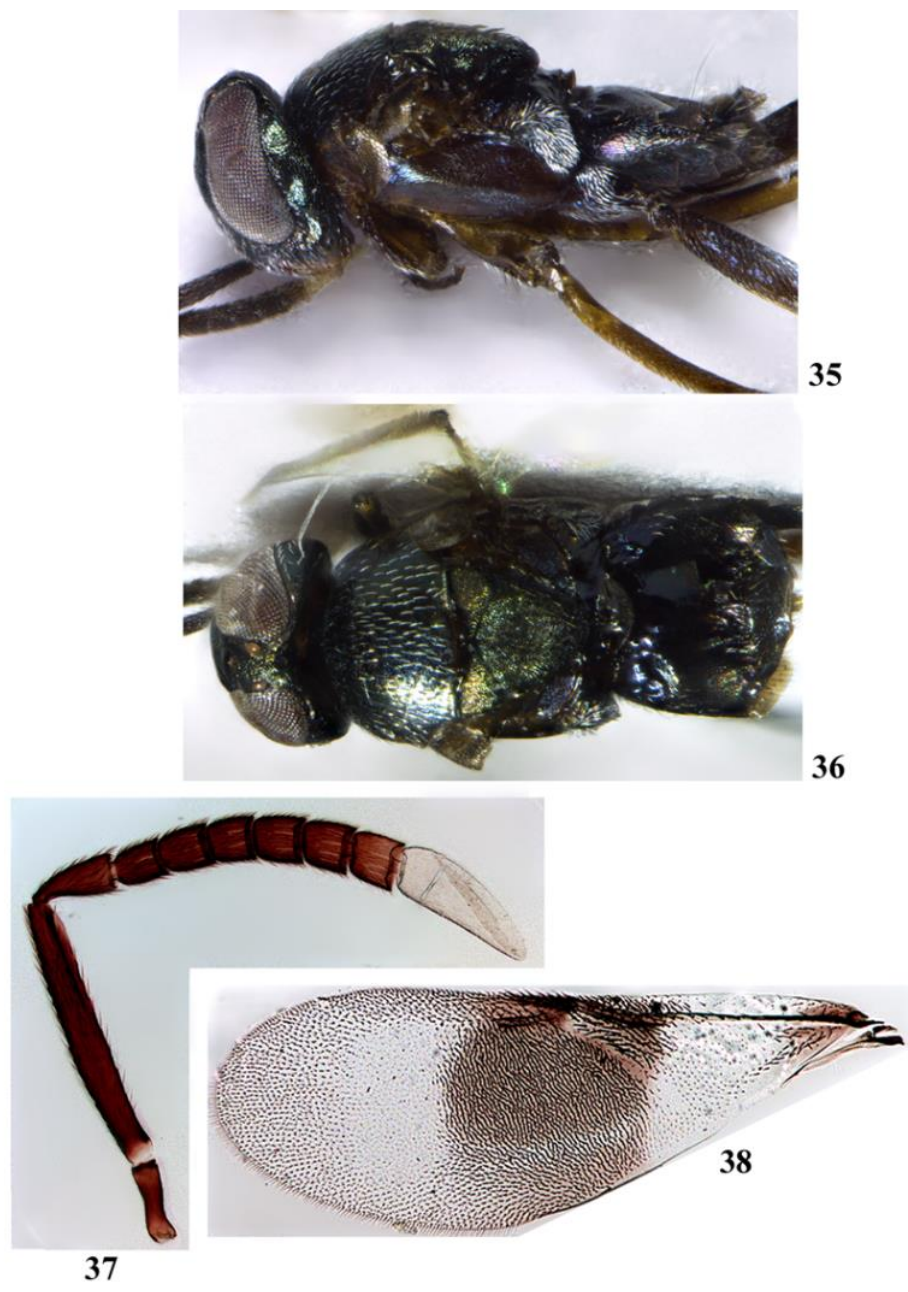

Figures 35-38. Homalotylus hemipterinus (De Stefani), female: 35. body, lateral view; 36. body, dorsal view; 37. antenna; 38 . fore wing. 
Material examined. 2 females (one antenna and one fore wing of one female on slide, No. EH.1880), 1 male. TURKEY: Adana, 4.ix.2014, Coll. A.F. Çalışkan (No. 11-b) and [with] Phenacoccus solenopsis. (ZDAMU)

Host. The real host of this species is some coccinellid beetle (Coleoptera: Coccinellidae) whose larvae feed on the mealybug, Phenacoccus solenopsis on Lantana camara.

Distribution. Turkey (new record). See Noyes (2015) for world distribution.

Comments. This is a well-known species with a wide distribution, and was recently considered by Noyes (2010). Therefore, we are only providing some relevant figures which may be of help in identifying this species in Turkey.

\section{Acknowledgments}

The authors (MRU, MBK, AFC) would like to thank Ç.Ü. Scientific Research Foundation (Project No. ZF2013BAP8) for their financial support. One of us (MH) particularly thanks the Indian Council of Agricultural Research, New Delhi and the Director, Dr. A. Verghese, National Bureau of Agricultural Insect Resources, Bengaluru and Coordinator of the Network Project on Insect Biosystematics, for financial help; the Aligarh Muslim University, Aligarh, and the Chairman, Department of Zoology, for providing research facilities; and Dr. J.S. Noyes, Natural History Museum, London, for his comments on the status of Leptomastix species dealt with in this paper which proved to be helpful in identifying the Turkish specimens as L. epona.

\section{References}

Abbas, G., M. J. Arif, M. Ashfaq, M. Aslam \& S. Saeed, 2010. The impact of some environmental factors on the fecundity of Phenacoccus solenopsis Tinsley (Hemiptera: Pseudococcidae): a serious pest of cotton and other crops. Pakistan Journal of Agricultural Sciences, 47(4): 321-325.

Agarwal, M. M. \& S. M. Alam, 1959. "New species of the genus Anagyrus Howard (Chalcidoidea: Encyrtidae) recorded from Aligarh" In: Proceedings of the $4^{\text {th }}$ Indian Science Congress, Part III: $392 \mathrm{pp.}$

Agarwal, M. M. 1965. Taxonomy of encyrtid parasites (Hymenoptera: Chalcidoidea) of Indian Coccoidea. Acta Hymenopterologica, Fukuoka, 2: 37-97.

Anga, J-M. \& J. S. Noyes, 1999. A revision of the African and Malagasy species of the genus Leptomastix (Hymenoptera, Encyrtidae), parasitoids of mealybugs (Homoptera: Pseudococcidae). Bulletin of the Natural History Museum London (Entomology), 68 (2): 93-128.

De Santis, L., 1964. Encirtidos de la Republica Argentina (Hymenoptera: Chalcidoidea). Anales de la Comisión de Investigación Cientifica Provincia de Buenos Aires Gobernación, 4: 9-422.

Fand, B. B. \& S. S. Suroshe, 2015. The invasive mealybug Phenacoccus solenopsis Tinsley, a threat to tropical and subtropical agricultural and horticultural production systems. Crop Protection, 69: 34-43.

Foerster, A., 1856. Hymenopterologische Studien. II Heft. Chalcidiae und Proctotrupii. 152 pp. Aachen.

García M., B. Denno, D. R. Miller, G. L. Miller, Y. Ben-Dov \& N. B. Hardy, 2015. ScaleNet: A Literature-based model of scale insect biology and systematics. (Web page: http://scalenet.info).

Graham, M. W. R. de V., 1969. Synonymic and descriptive notes on European Encyrtidae (Hym., Chalcidoidea). Polskie Pismo Entomologiczne, 39 (2): 211-319.

Hayat, M., 2003. Records and descriptions of Indian Encyrtidae (Hymenoptera: Chalcidoidea). Oriental Insects, 37: 187-259.

Hayat, M., 2006. Indian Encyrtidae (Hymenoptera: Chalcidoidea).Published by M. Hayat, Department of Zoology, Aligarh Muslim University, India viii + 496 pp.

Howard, L. O. 1894. Report upon the parasitic Hymenoptera in the island of St. Vincent. Journal of the Linnean Society (Zoology), 25: 56-254.

Kaydan, M. B., Çalışkan, A. F. \& M. R. Ulusoy, (2013). New record of invasive mealybug Phenacoccus solenopsis Tinsley (Hemiptera: Pseudococcidae) in Turkey. EPPO Bulletin, 43: 169-171. 
Kosztarab M. \& F. Kozár, 1988. Scale Insects of Central Europe. Akademiai Kiado, Budapest, Hungary, and Dr W. Junk Publishers, Dordrecht, The Netherlands, $456 \mathrm{pp}$.

Mayr, G., 1876. Die europäischen Encyrtiden. Verhandlungen der Zoologisch-Botanischen Gessellschaft in Wien, 25, 675-778.

McKenzie, H. L., 1967. Mealybugs of California with taxonomy, biology, and control of North American species (Homoptera: Coccoidea: Pseudococcidae). California: University of California Press.

Mercet, R. G., 1921. Fauna Ibérica Himenópteros Fam. Encírtidos. Museo Nacional de Ciencias Naturales, Madrid, Spain, 727 pp.

Noyes, J. S. \& M. Hayat, 1994. Oriental Mealybug Parasitoids of the Anagyrini (Hymenoptera: Encyrtidae).CAB International, Wallingford, Oxon, UK, viii + 554 pp.

Noyes, J. S., 2000. Encyrtidae of Costa Rica (Hymenoptera: Chalcidoidea), 1. Memoirs of the American Entomological Institute, 62: 1-355.

Noyes, J. S., 2010. Encyrtidae of Costa Rica (Hymenoptera: Chalcidoidea), 3. Memoirs of the American Entomological Institute, 84: 1-848.

Noyes, J. S., 2015. Universal Chalcidoidea Database. (Web page: http://www.nhm.ac.uk/researchcuration/projects/chalcidoids) (Date accessed: 30 December 2015).

Özdikmen, H., 2011. New names for some preoccupied specific epithets in Chalcidoidea I: Families Agaonidae, Aphelinidae, Chalcididae, Encyrtidae, Eulophidae (Hymenoptera: Parasitica). Munis Entomology \& Zoology, 6 (2): 796-814

Triapitsyn, S. V., D. González, D. B. Vickerman, J. S. Noyes \& E. B. White, 2007. Morphological, biological, and molecular comparisons among the different geographical populations of Anagyrus pseudococci (Hymenoptera: Encyrtidae), parasitoids of Planococcus spp. (Hemiptera: Pseudococcidae), with notes on Anagyrus dactylopii. Biological Control, 41: 14-24.

Trjapitzin, V. A., 1989. Parasitic Hymenoptera of the fam. Encyrtidae of Palaearctics. Opredeleteli po Faune SSSR, Izdavavaemiye Zoologicheskim Institutom Akademii Nauk SSSR, 158: 1-489.

Walker, F., 1844. Descriptions of some British chalcidites. Annals and Magazine of Natural History, 14: $181-185$.

Williams, D. J., 2004. Mealybugs of Southern Asia. The Natural History Museum, London, UK and Southdene SDN. BHD., Kuala Lumpur, Malaysia, 896 pp. 